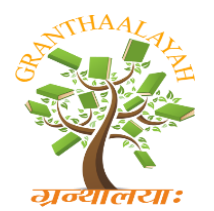

\author{
INTERNATIONAL JOURNAL OF RESEARCH - \\ GRANTHAALAYAH \\ A knowledge Repository
}

Management

\title{
AN ECONOMIC STUDY OF PADDY CULTIVATION IN KANYAKUMARI DISTRICT
}

\author{
Mrs. S. Anitha Jose ${ }^{* 1}$ \\ ${ }^{* 1}$ Asst. Prof. B.Com (CA), Nanjil Catholic College of Arts \& Science, Kaliyakkvilai, INDIA
}

DOI: https://doi.org/10.29121/granthaalayah.v4.i10(SE).2016.2474

\begin{abstract}
Agricultural is the backbone of India. In India, majority of the places are occupied by agricultural land. There are lot of people working in this sector. Unfortunately the farmers are very poor in the economical level. Paddy cultivation is the major cultivation in agricurture sector. This paper is going to study about the status of agricultural farmers. Factors influencing to choose the agricutute and reasons for the poor economic level of the farmers. It is concluded that farmers in kanyakumari District Prefer agriculture mainly due to the availability of land. The advanced technologies should be used in the agriculture sector to make more profits in agriutural activites. Thus, the farmers will be economically sound and so on.
\end{abstract}

Keywords:

Agricuture, Farmers, Economic, Indian Economy, Paddy \& Livelihood.

Cite This Article: Mrs. S. Anitha Jose, "AN ECONOMIC STUDY OF PADDY CULTIVATION IN KANYAKUMARI DISTRICT" International Journal of Research Granthaalayah, Vol. 4, No. 10: SE (2016): 63-69.

\section{INTRODUCTION}

Agriculture has been and will continue to be the life line of the Indian economy. As the largest private enterprise in India agriculture contributes nearly one fourth of the national GDP, Sustains livelihood. Of about two thirds of population and is the back bone of agro based industry. If food Sector alone agriculture contributes about Sector along agriculture contributes about Rs. 250 Thousand annually.

Through the update of modern Agricultural technologies India has moved from an era of chronic food shortages and bagging bowl Status up to 1960s to food self- sufficiency and even food exports. At the time, issues on arresting decreasing factor productivity and improving resource use efficiency have become important. The technology led Sustainable growth in almost all the 
Sectors is important. Since 1950, the Productivity grains, 1.6 times in fruits 2.1 times in Vegetables 5-6 times in Fish (aquaculture) 1.8 times in milk and 4.8 times in eggs.

\section{REVIEW OF LITERATURE}

Y.L. Das and Manohar Lal in their Paper "Pattern of Agriculture Marketing" Study the marketing functions, which include primarily the assembling of the Produce. There are difficulties in this, as there is a wide Variation in the quality of a Particular produce farm to farm. The commodities have to be marketed in large quantities so as to secure economy in transport while at the same time adjusting the supply to the consumers demand for variety. Adequate facilities like financial assistance have to be provided for the storage of the assembled produce. Those who acquire ownership of the produce during the marketing Process have to assume risk of various kinds which include risk of loss due to fall in price, danger of deterioration in quality or of total destruction of the Produce. Before the actual sale takes place, the produce has to be graded. Transportation is the last process in this chain and often the Success of marketing function very largely depends on the cost and facilities of transport.

D.S. Sindhu in his Paper "Some aspects of agricultural marketing and pricing policies in India" takes marketing efficiency and improved in two ways.

- By increasing operational efficiency

- By increasing Pricing efficiency.

The Former focuses on cost effectiveness, that is reducing cost involved in the Performance of difference marketing functions like transportation, storage, processing etc. the latter refers to the Structural characteristics of the market in system where the sellers got true value of their produce and the consumers receive the true worth of their money. Generally, the two types are mutually reinforcing in the long run. One without the other is not enough.

C.H. Hanumanth Rao and K. Subba Rao in their paper "Marketing of Rice in India - An analysis of the impact of produce's Prices on Small Farmers' (1976) also study the relation of spatial and seasonal differences in prices to transport and storage cost, and thereby ascertain the efficiency of "Marketing system in the sense of establishing prices".

According to K. Ponnusamy agricultural marketing involves its simplest form of buying and selling of agricultural produce. In modern agricultural marketing, it has three important functions; namely,

Assembling (concertation), Preparation for consumption (Processing) and Distribution (dispersion).

The importance of efficient marketing system was at first recognized by the Royal Commission on Agriculture in its report in the year 1928. As a result of the commission's recommendation, the Government of India enacted Agricultural Produce and marketing Act (APGMA) in 1937. Promotion of grading and standardization of agricultural products is covered under this act. The scheme comprises the grading at two levels namely, Consumer level and Producer level or farmer level. 
S.S. Nagarajan engaged in rice research for the past 40 years purchased a rise called "jilakara Ponni" (JP) at Madras from an Andhra rice merchants paying a price of Rs. 20 per $\mathrm{kg}$ in the retail market. The rice looks slender and appears to be much finer that the popular table rice of Tamilnadu viz., white ponni. In the Chennal market, the Jilakara ponni rice has attracted the attention of consumers because the cooking quality of rice is excellent and it is slowly becoming the connoisseur's first choice. The JP Paddy is spreading fast like a wild fire without any one taking any special; extension efforts.

\section{OBJECTIVES OF THE STUDY}

1) To know the Scope for Paddy cultivation in Kanyakumari District.

2) To know the modern technologies that can be applied in agriculture.

3) To analyse to the various problems faced by the Paddy cultivators in cultivation, getting yield and marketing of Paddy.

\section{STATEMENT OF THE PROBLEM}

In India the magnitude and intensity of crops grown in the region depends on soil and bioClimate conditions, Socio- economic status of farmers and opportunities for marketing the surplus. The growing period is variable from one agro Climatic Zone to other that affects the Vegetative and reproductive period leading to differences in potential yield. The important factors affecting the Productivity are seeding time and method dogy, crop establishment and climatic conditions during the growing season. Farmers generally take more than crop in a year to maximize the production and profits. Indian agriculture has witness a gradual transformation from subsistence farming of early fifties to the present intensive agriculture especially in betterendowed regions, where basic infrastructure essential for translating potential of improved technologies into reality was created along with favorable government policies.

In Kanyakumari District, agriculture is the prime activity of nearly $60 \%$ of the people where paddy is the major crop cultivated all over the district. Paddy us cultivated in two seasons namely April-September and October March with the time period of six months. Rice is the major food consumed by the people of this district and hence the consumption is also being very high there is a high score for paddy cultivation and marketability. Paddy is cultivated nearly 40,000 hectares of land in the district. Since this crop has high scope in all the respects, this study aims to analyse the economic benefits derived by the Paddy cultivators in kanyakumari district and also to bring into light the problems faced by them and also suggest remedical measures to overcome their problems.

\section{TOOLS OF ANALYSIS}

The collected date have been properly processed and tabulated for the purpose of the study. The tabulated figures are analyzed with proper statistical tools. Besides usage of charts, graphs etc. The following formulas have been applied to arrive at a valid conclusion.

$\mathrm{X}=(\mathrm{O}-\mathrm{E})^{2}$

$\mathrm{E}$

$\mathrm{E}=\mathrm{CT} . \mathrm{RT}$ 
$\mathrm{N}$

To find the association between the chosen factors $\mathrm{C}$ test has been applied with the help of the following formula

$\mathrm{C}=\mathrm{X} 2$

$\mathrm{N}=\mathrm{X} 2$

Apart from these weighted rank have been applied wherever necessary to analyze the various problems and Suggestions.

\section{ASSOCIATION BETWEEN PROFILE OF PADDY CULTIVATIONS}

Paddy cultivation plays a prominent role in Kanyakumari district where most of the farmers depend upon it since paddy is an important food product of south India, it is being imperative to improve the same. Hence this study is an attempt to extract the inherent factors lies in the development of paddy cultivation in this district. The survey conducted among hundred paddy farmers of this district reveals the following.

\begin{tabular}{|l|l|l|l|}
\hline S.No. & Age (Years) & Number of Members & Percentage (\%) \\
\hline 1. & $20-40$ & 26 & 26 \\
\hline 2. & $41-60$ & 67 & 67 \\
\hline 3. & Above 60 & 7 & 7 \\
\hline & Total & $\mathbf{1 0 0}$ & $\mathbf{1 0 0}$ \\
\hline S.No. & Marial Status & Number of Members & Percentage (\%) \\
\hline 1. & Married & 95 & 95 \\
\hline 2. & Un Married & 5 & 5 \\
\hline & Total & $\mathbf{1 0 0}$ & $\mathbf{1 0 0}$ \\
\hline S.No. & Education & Number of Members & Percentage (\%) \\
\hline 1. & Primary & 22 & 22 \\
\hline 2. & Higher Secondary & 34 & 34 \\
\hline 3. & Graduates & 29 & 29 \\
\hline 4. & Post Graduates & 15 & 15 \\
\hline & Total & $\mathbf{1 0 0}$ & $\mathbf{1 0 0}$ \\
\hline S.No. & Occupation & Number of Members & Percentage (\%) \\
\hline 1. & Employed & 28 & 28 \\
\hline 2. & Business & 21 & 21 \\
\hline 3. & Farmers & 51 & 51 \\
\hline & Total & $\mathbf{1 0 0}$ & $\mathbf{1 0 0}$ \\
\hline S.No. & Family Members & Number of Members & Percentage (\%) \\
\hline 1. & $3-6$ & 72 & 72 \\
\hline 2. & $7-10$ & 19 & 19 \\
\hline 3. & $11-13$ & 6 & 6 \\
\hline 4. & $14-17$ & 3 & 3 \\
\hline & Total & $\mathbf{1 0 0}$ & $\mathbf{1 0 0}$ \\
\hline
\end{tabular}




\begin{tabular}{|l|l|l|l|}
\hline S.No. & Income (Rs) & Number of Members & Percentage (\%) \\
\hline 1. & Below 40,000 & 36 & 36 \\
\hline 2. & $40,000-80,000$ & 34 & 34 \\
\hline 3. & $80,000-1,20,000$ & 19 & 19 \\
\hline 4. & 120000 \& Above & 11 & 11 \\
\hline & Total & $\mathbf{1 0 0}$ & $\mathbf{1 0 0}$ \\
\hline S.No. & Area (acres) & Number of Members & Percentage (\%) \\
\hline 1. & Up to 1 & 53 & 53 \\
\hline 2. & 2 & 17 & 17 \\
\hline 3. & 3 & 9 & 9 \\
\hline 4. & 4 & 12 & 12 \\
\hline 5. & $5 \&$ above & 9 & 9 \\
\hline & Total & $\mathbf{1 0 0}$ & $\mathbf{1 0 0}$ \\
\hline
\end{tabular}

Source: Primary Data

It is clear from the 67 per cent respondents belong to the age group of 41-60,26\% to 21-40, and one per cent respondents belong to the age group of above 60 . Thus most of the members belong to the middle age of 40-60. Generally this factor determines the earning capacity and the different needs of the people and they act accordingly.

95 per cent respondents are married and the balance 5 per cent respondents are unmarried. Usually married people work hard to earn their living than unmarried.

Education implies very vital role in this area. 34 per cent respondents studied higher secondary level, 29 per cent respondents are graduate, 22 per cent respondents studied primary level and 15 per cent respondents are post graduate.

51 per cent respondents are farmers, 28 per cent respondents employed and 21 per cent respondents are businessmen. Occupation irrespective of the Profession, people of Kanyakumari district involved in agriculture because there ample chances for the same. Dependence of most of the people is agriculture only.

72 per cent respondents have 3-6 family members, 19 per cent respondents have 7-10 family members, 6 per cent respondents have 11-13 family members and 3 per cent respondents have 14 - 17 family members Number of the family members is more their needs will also increase and vice Versa most of them belong to Small family six only.

36 per cent respondents' income is Rs. 40,000, 34 per cent respondents' income is Rs. 40,000 $80,000,19$ per cent respondents' income is Rs. 80,000 - 1, 20,000 and 11 per cent respondents' income is above Rs. 1, 20,000. Thus, the Earning capacity of the sample respondents is good.

53 per cent respondents have only one acre agricultural land, 17 per cent respondents have 2 acres land, 12 per cent respondents have 4 acres land and 9 per cent respondents have 3 and 5 more acres land. Most of the Land owners have a small piece of land to the extent of the maximum of one acre. 


\section{PREFERENCE OF AGRICULTURE}

The question often arises as to why the people prefer agriculture to other jobs. A few options are given like tradition, unemployment self, interest, climate conditions. To earn additional income, family property easy marketability and the usage of agriculture products for family use. The Survey result is being below.

\begin{tabular}{|l|l|l|l|}
\hline S.No. & Reasons & Percentage $\mathbf{( \% )}$ & Rank \\
\hline 1. & Tradition & 28 & II \\
\hline 2. & Unemployment & 3 & VII \\
\hline 3. & Self interest & 11 & III \\
\hline 4. & Climatic conditions & 4 & VI \\
\hline 5. & Additional income & 5 & V \\
\hline 6. & Family Property & 38 & I \\
\hline 7. & Easy marketability & 2 & VIII \\
\hline 8. & For family use & 9 & IV \\
\hline & Total & $\mathbf{1 0 0}$ & \\
\hline
\end{tabular}

Source: Primary Data

As per the Survey 38 per cent respondents prefer agriculture because they have family Properties, followed by 28 per cent respondents prefer for the reason of traditional, 11 per cent respondents prefer due to their self-interest, 9 per cent respondents for the purpose of using the agriculture products for family usage 5 per cent respondents prefer because of earning additional income 4 per cent respondents prefer due to favorable climatic conditions, 3 per cent respondents prefer due to unemployment and for 2 per cent respondents prefer for easy marketability. It is concluded that farmers in kanyakumari District Prefer agriculture mainly due to the availability of land. The same can be depicted with help of a charlas under.

\section{CONCLUSION}

Massive changes are bringing in new Social and economic shifts, which include globalization of markets, technology democratization of information exponential increase in competition weather creation and the emergence of knowledge -world market. A lot of changes have taken Place over the last 55 years in the country both in the research and extension should result in happy farming system hunger and malnutrition, free India, environmental security, social and gender equity. There is a need for integration of efforts to solve the common problems facing the farming community. The investment in material is required to be shifted to investment in people so as to build human resource with improvement in educational Standards and competency building on terms of Organizational, managerial communicational and entrepreneurial Skills. Excellence is hard to perceive, harder to achieve, but once achieved is even harder to ignore Excellence will certainly add substantially to the Successful sailing of the extension education System. 


\section{REFERENCES}

[1] D.S.Sindhu "Some Aspects of Agricultural Marketing and Pricing Policies in India. Indian Journal of Agricultural Economics Vol XLV, No.4 October - December 1990 Pp 433-434.

[2] Franco, C. E., \& Regi, S. B. (2016). ADVANTAGES AND CHALLENGES OF E COMMERCE CUSTOMERS AND BUSINESSES: IN INDIAN PERSPECTIVE. International Journal of Research-GRANTHAALAYAH A Knowledge Repository, 4 (3), 7, 13.

[3] Golden, S. A. R. (2014). A Descriptive Study On The Role Of Consumer Psychology And Behaviour In Product Purchasing. Indian Streams Research Journal, 3 (12), 1, 6.

[4] K. Ponnusamy, "Agricultural Marketing in Kanyakumari District” Gazetteers of India, 1995. Pp.285-291.

[5] N.Nadarajan, V.sivasubramanian and S.Chelliah, "Rice Cultivation in TamilNadu Not Profitable”, Kisan World, October 1990, Pp.24-26.

[6] Regi, S. B. (2016). Prospectus \& Challenges Of Women Entrepreneurs-A Study With Special Reference To Tirunelveli District. International Journal Of Scientific Research And Modern Education, 786, 792.

[7] Regi, S. B., \& Franco, C. E. (2014). A DESCRIPTIVE STUDY ON THE PROSPECTS OF E-COMMERCE IN INDIA. Golden Research Thoughts, 3 (9), 1, 7.

[8] Regi, S. B., \& Franco, C. E. (2014). Reforms In Insurance Sector In India-A Empirical Study. Review Of Research, 3 (9), 1, 5.

[9] Regi, S. B., \& Franco, C. E. (2014). SELF EMPLOYMENT AS SUSTAINABLE EMPLOYMENT"'-A STUDY ON SELF EMPLOYED WOMEN'S ASSOCIATION (SEWA) GUJARAT, INDIA. Indian Streams Research Journal, 4 (2), 1, 5.

[10] Regi, S. B., (2014). Foreign Direct Investment-An Overview. IJARCSMS, 2 (2).

[11] S.S. Nagarajan, 'Jilakara Ponni A Rice Variety', Kisan World. Vol.26, No.10 October 1999

[12] Y.L .Das Manohar Lal "Pattern of Agricultural Marketing” Kurukshetra,Vol XI, VI No 6 March 1998 P.12 